\title{
A comparison of protein polymorphisms in milk produced by two dairy farms in West Pomerania
}

\begin{abstract}
The aim of the study was to compare the frequencies of protein polymorphisms in milk produced by cows with various proportion of HF genes within their genotypes, managed in two farms.

Frequency analyses of beta-lactoglobulin (BLG) and three casein fractions (CSN1S1, CSN2, and CSN3) in individual genetic groups of animals were carried out in milk of 342 cows. Also, milk content of casein and whey proteins was assayed.

The highest level of casein was found in farm $\mathrm{B}$, in all the genotypic groups of cows, while the proportion of whey proteins in milk was highest in farm A, in the genotypic group of cows with $25 \%$ to $50 \%$ of $\mathrm{HF}$ genes. As far as the remaining groups of cows are concerned, the level of whey proteins was equal in both studied farms. A genetic differentiation of polymorphisms in milk protein was found in the analysed farms. Frequency of kappa-casein B (CSN3 B) genetic variants, which are desired in processing, was higher in farm A.
\end{abstract}

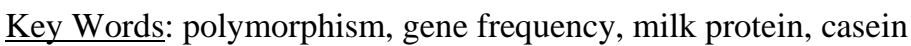

\section{Zusammenfassung}

Titel der Arbeit: Vergleich von Polymorphismen der Milchproteine aus zwei Betrieben in Westpommern Das Ziel dieser Arbeit war ein Vergleich der Polymorphismen von Milcheiweiß in Kuhpopulationen mit verschiedenem Holstein-Friesian-Genanteil in zwei Betrieben.

Die Untersuchungen über das Auftreten von Genotypen Beta-Laktoglobulin (BLG) und drei Kaseinfraktionen (CSN1S1, CSN2 und CSN3) in einzelnen genetischen Gruppen wurden an Milchproben von 342 Kühen durchgeführt, wobei auch der Gehalt an Kasein und Molkeprotein in der Milch bestimmt wurde.

Der größte Kaseingehalt in der Milch wurde im Betrieb B in allen Genotypgruppen festgestellt; der prozentuelle Anteil an Molkeeiweiß in der Milch war dagegen im Betrieb A in den Genotypgruppen mit einem HF-Anteil von $25 \%$ bis 50 \% am höchsten; in den übrigen Genotypgruppen war er in beiden untersuchten Betrieben gleich.

In den ausgewerteten Betrieben wurde eine genetische Differenzierung der Polymorphismen von Milcheiweiß festgestellt. Die Frequenz des Auftretens von genetischen Varianten des Kappa-Kaseins B (CSN3 B), die günstig hinsichtlich einer technologischen Eignung ist, war im Betrieb A größer.

Schlüsselwörter: Polymorphismus, Genfrequenz, Milcheiweiß, Kasein

\section{Introduction}

The studies on protein polymorphism application in cattle genetics, which have been extensive over the recent years, indicate that milk proteins can be utilised in both breeding practice and milk processing (LITWIŃCZUK et al., 1998b; GRAML and PIRCHNER, 2003). Presence and frequencies of milk protein encoding alleles are different in individual breeds of cows (JANN et al., 2002), the differences being detectable between herds of cattle within a single breed (JUSZCZAK et al., 2001; FREYER et al., 1998).

Nutritive value of milk is determined primarily by total protein content, whereas its technological value depends on the proportion of its desired (genetically determined) 
fractions, particularly casein, which represents about $75-85 \%$ of total milk proteins. The aim of the study was to compare the frequencies of polymorphisms in proteins of milk obtained from two populations of cows, with various HF genes proportion in the genotype and managed in two large-herd farms.

\section{Material and methods}

The frequency analyses of beta-lactoglobulin (BLG), alpha-casein S1 (CSN1S1), betacasein (CSN2), and kappa-casein (CSN3) were carried out on 342 Black-and-White (BW) cows with varying proportion of Holstein-Friesian (HF) genes in their genotype. The cows in the farm A were managed in pasture-housing system, while the cows in the farm B were kept only indoors, in confinement.

Milk samples were collected during test days from cows being in milk between 60 and 120 days. The samples were placed in 100 -ml plastic containers. The analyses were done immediately on having transported the samples to the laboratory. The analyses did not include samples taken from cows showing symptoms of mastitis, or samples of milk that displayed abnormal properties observed during the precipitation of the proteins.

Both beta lactoglobulin and the three mentioned casein phenotypes were tested twice on starch gel in alkaline environment, according to SCHMIDT (1964), modified by MICHALAK (1969), and in acid environment, according to PETERSON and KOPFLER (1966).

Casein content was arrived at from the difference between total protein and the content of whey proteins.

Total protein was assayed using a Pro-Milk instrument (Foss Electric, Denmark), while whey proteins were assayed using the calorimetric technique with $10 \mathrm{~B}$ amide black, according to ASCHAFFENBURG and DREWRY (1959). The standardisation curve for total whey protein was created with the Kjeldahl method.

The obtained results enabled an estimation of the number of all phenotypes of casein and beta lactoglobulin, which in turn allowed estimating the frequencies of genes and genotypes. Genetic equilibrium was analysed according to the Hardy-Weinberg law, while the chi-square test was used for testing the fitness of the empirical data to their theoretical distribution (RUSZCZYC, 1978).

\section{Results}

Table 1 presents protein content and frequencies of milk protein polymorphisms in relation to genotypes of cows in farms A and B.

The highest level of total protein (3.09\%) was obtained in farm B from cows of 75$100 \% \mathrm{HF}$, whereas the lowest (2.93\%) was found in barn A from cows of $50-75 \% \mathrm{HF}$. The highest casein content (2.47\%) was recorded in farm B in cows with more than $75.1 \%$ HF genes, while the lowest was in farm A (2.31\%) in the group of cows with $50-75 \%$ HF. The highest content of whey proteins was observed in farm A (0.66\%) in cows of the genotype $25-50 \% \mathrm{HF}$, while the lowest was obtained in farm B $(0.57 \%)$ in the same group of cows.

The highest frequency of CSN1S1 phenotypes was found in milk of cows with $75 \%$ to $100 \%$ HF genes in farm B, where two variants were observed, B and BC, depending on the presence of two alleles, i.e. CSN1S1 B and CSN1S1 C. In the genotypic group 
of cows with $25-50 \% \mathrm{HF}$, only one phenotype of this protein, $\mathrm{B}$, was found with no BC phenotype in either farm. The total number of CSN1S1 B phenotypes was higher in farm A within the genotypic group of 50-75\% HF.

Table 1

Number of milk protein polymorphism phenotypes by cow genotype in the studied farms (Anzahl Phänotypen der Milchproteinstrukturen unter Berücksichtigung der Kuhgenotypen in untersuchten Betrieben)

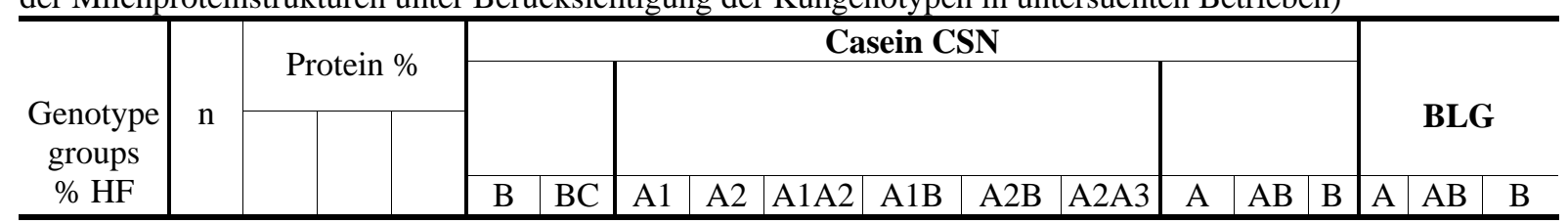

Farm A

\begin{tabular}{|c|c|c|c|c|c|c|c|c|c|c|c|c|c|c|c|c|c|c|}
\hline $25-50$ & 12 & 3.05 & 2.40 & 0.66 & 12 & 0 & 4 & 6 & 0 & 1 & 1 & 0 & 7 & 4 & 1 & 4 & 5 & 3 \\
\hline $50-75$ & 57 & 2.93 & 2.31 & 0.60 & 54 & 3 & 11 & 17 & 22 & 4 & 3 & 0 & 31 & 24 & 2 & 0 & 27 & 30 \\
\hline $75-100$ & 102 & 3.03 & 2.40 & 0.62 & 101 & 1 & 21 & 29 & 37 & 8 & 6 & 1 & 56 & 39 & 7 & 8 & 54 & 40 \\
\hline Total & 171 & - & - & - & 167 & 4 & 36 & 52 & 59 & 13 & 10 & 1 & 94 & 67 & 10 & 12 & 86 & 73 \\
\hline \multicolumn{19}{|c|}{ Farm B } \\
\hline $25-50$ & 19 & 3.00 & 2.43 & 0.57 & 19 & 0 & 5 & 4 & 9 & 0 & 1 & 0 & 17 & 2 & 0 & 1 & 8 & 10 \\
\hline $50-75$ & 41 & 3.05 & 2.45 & 0.60 & 39 & 2 & 8 & 12 & 12 & 2 & 6 & 1 & 26 & 15 & 0 & 2 & 23 & 16 \\
\hline $75-100$ & 111 & 3.09 & 2.47 & 0.62 & 106 & 5 & 18 & 27 & 55 & 6 & 4 & 1 & 80 & 27 & 4 & 19 & 46 & 46 \\
\hline Total & 171 & - & - & - & 164 & 7 & 31 & 43 & 76 & 8 & 11 & 2 & 123 & 44 & 4 & 22 & 77 & 72 \\
\hline $\begin{array}{c}\text { Grand } \\
\text { total }\end{array}$ & 342 & & & & 331 & 11 & 67 & 95 & 135 & 21 & 21 & 3 & 217 & 111 & 14 & 34 & 163 & 145 \\
\hline
\end{tabular}

Within the CSN2 of milk, the following six variants were found: A1, A2, A1A2, A1B, $\mathrm{A} 2 \mathrm{~B}$, and A2A3, encoded by four alleles, i.e. CSN2 A1, CSN2 A2, CSN2 A3, CSN2 B. The A2A3 phenotype was not found in the groups $25-50 \%$ or $50-75 \%$ HF in farm $\mathrm{A}$, while in farm B in the group $25-50 \% \mathrm{HF}$.

Within the CSN3 of milk, three variants were found, $A, A B$, and $B$, whose occurrence was controlled by two alleles, CSN3 A and CSN3 B. In farm B the phenotype B was not found in the groups $25-50 \% \mathrm{HF}$ and $50-75 \% \mathrm{HF}$. The total number of CSN3 A phenotypes was higher in farm $\mathrm{B}$, while CSN3 AB were more frequent in farm $\mathrm{A}$.

Three phenotypes were found in the BLG polymorphism, $A, A B$, and $B$, determined by two BLG alleles, BLG A and BLG B. The phenotype A was not found in the group $50-75 \%$ HF in farm A. The total frequency of BLG phenotypes, $A B$ and $B$, was higher at farm A, while BLG A phenotypes were more frequent at farm B.

Table 2 presents frequency of the genes encoding for milk protein polymorphisms as well as empirical and theoretical distribution of genotypes in the studied population of cows with varying content of HF genes at farm A.

As far as CSN3 is concerned, 58.33\% of the 25-50\% HF individuals were homozygotes AA, which was a consequence of a high frequency of the CSN3 A allele (0.75). A2A2 homozygous individuals also prevailed in CSN2, constituting $50 \%$ of the population. For polymorphisms in CSN3 and CSN2, a lack of genetic equilibrium was found, which resulted from a significant difference between empirical and theoretical genotype distributions; in the remaining cases the chi-square values were lower than theoretical one. In the polymorphism of BLG, heterozygous AB animals constituted 
for $41.67 \%$.

Table 2

Frequencies of genes controlling milk protein polymorphism as well as observed and theoretical distribution of genotypes with different proportion of HF cattle genes in farm A (Genfrequenz des Milchproteinpolymorphismus sowie beobachtete und theoretische Genotypenverteilung in der untersuchten Kuhpopulation mit verschiedenem HF- Genanteil im Betrieb A)

\begin{tabular}{|c|c|c|c|c|c|c|c|c|c|}
\hline$\% \mathrm{HF}$ & Milk protein & $\begin{array}{l}\text { Geno- } \\
\text { types }\end{array}$ & $\begin{array}{c}\text { Observed } \\
\text { number of } \\
\text { individuals }\end{array}$ & $\%$ & Gene & equency & $\begin{array}{l}\text { Genotype } \\
\text { frequency }\end{array}$ & $\begin{array}{l}\text { Theoretical } \\
\text { number of } \\
\text { indivduals }\end{array}$ & Chi2 \\
\hline \multirow{3}{*}{ 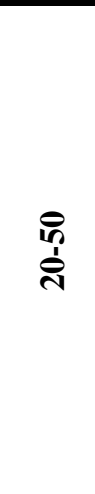 } & CSN3 & $\begin{array}{l}\mathrm{AA} \\
\mathrm{AB} \\
\mathrm{BB}\end{array}$ & $\begin{array}{l}7 \\
1 \\
4\end{array}$ & $\begin{array}{l}58.33 \\
8.33 \\
33.33 \\
\end{array}$ & $\begin{array}{l}A= \\
B=\end{array}$ & $\begin{array}{l}0.75 \\
0.25\end{array}$ & $\begin{array}{l}0.5625 \\
0.3750 \\
0.0625\end{array}$ & $\begin{array}{l}6.75 \\
4.50 \\
0.75\end{array}$ & $16.815^{*}$ \\
\hline & CSN2 & $\begin{array}{l}\text { A1 } \\
\text { A2 } \\
\text { A1A2 } \\
\text { A1B } \\
\text { A2B } \\
\text { A2A3 }\end{array}$ & $\begin{array}{l}4 \\
6 \\
0 \\
1 \\
1 \\
0\end{array}$ & $\begin{array}{l}33.33 \\
50.00 \\
0.00 \\
8.33 \\
8.33 \\
0.00\end{array}$ & $\begin{array}{c}\mathrm{A} 1= \\
\mathrm{A} 2= \\
\mathrm{A} 3= \\
\mathrm{B}=\end{array}$ & $\begin{array}{c}0.375 \\
0.542 \\
0 \\
0.083\end{array}$ & $\begin{array}{l}0.1406 \\
0.2938 \\
0.4065 \\
0.0623 \\
0.0900 \\
0.0000\end{array}$ & $\begin{array}{l}1.69 \\
3.53 \\
4.47 \\
0.87 \\
6.03 \\
0.00 \\
\end{array}$ & $13.591^{*}$ \\
\hline & BLG & $\begin{array}{l}\mathrm{AA} \\
\mathrm{AB} \\
\mathrm{BB}\end{array}$ & $\begin{array}{l}4 \\
5 \\
3 \\
\end{array}$ & $\begin{array}{l}33.33 \\
41.67 \\
25.00 \\
\end{array}$ & $\begin{array}{l}A= \\
B=\end{array}$ & $\begin{array}{l}0.542 \\
0.458\end{array}$ & $\begin{array}{l}0.2938 \\
0.4965 \\
0.2098 \\
\end{array}$ & $\begin{array}{l}3.53 \\
5.96 \\
2.52 \\
\end{array}$ & 0.311 \\
\hline \multirow{4}{*}{ 旡 } & CSN1S1 & $\begin{array}{l}\mathrm{BB} \\
\mathrm{BC} \\
\mathrm{CC}\end{array}$ & $\begin{array}{c}54 \\
3 \\
0\end{array}$ & $\begin{array}{r}94.74 \\
5.26 \\
0.00\end{array}$ & $\begin{array}{l}B= \\
C=\end{array}$ & $\begin{array}{l}0.974 \\
0.026\end{array}$ & $\begin{array}{l}0.9487 \\
0.0506 \\
0.0007\end{array}$ & $\begin{array}{c}54.07 \\
2.89 \\
0.04\end{array}$ & 0.043 \\
\hline & CSN3 & $\begin{array}{l}\mathrm{AA} \\
\mathrm{AB} \\
\mathrm{BB}\end{array}$ & $\begin{array}{c}31 \\
24 \\
2\end{array}$ & $\begin{array}{r}54.39 \\
42.11 \\
3.51\end{array}$ & $\begin{array}{l}A= \\
B=\end{array}$ & $\begin{array}{l}0.754 \\
0.246\end{array}$ & $\begin{array}{l}0.5685 \\
0.3710 \\
0.0605\end{array}$ & $\begin{array}{c}32.41 \\
21.15 \\
3.45\end{array}$ & 1.055 \\
\hline & CSN2 & $\begin{array}{l}\text { A1 } \\
\text { A2 } \\
\text { A1A2 } \\
\text { A1B } \\
\text { A2B } \\
\text { A2A3 }\end{array}$ & $\begin{array}{c}11 \\
17 \\
22 \\
4 \\
3 \\
0\end{array}$ & \begin{tabular}{r|}
19.30 \\
29.82 \\
38.60 \\
7.02 \\
5.26 \\
0.00 \\
\end{tabular} & $\begin{array}{l}\mathrm{A} 1= \\
\mathrm{A} 2= \\
\mathrm{A} 3= \\
\mathrm{B}=\end{array}$ & $\begin{array}{c}0.421 \\
0.518 \\
0 \\
0.061\end{array}$ & $\begin{array}{l}0.1772 \\
0.2683 \\
0.4362 \\
0.0514 \\
0.0632 \\
0.0000 \\
\end{array}$ & $\begin{array}{c}10.10 \\
12.34 \\
24.42 \\
3.29 \\
3.79 \\
0.00 \\
\end{array}$ & 2.397 \\
\hline & BLG & $\begin{array}{l}\mathrm{AA} \\
\mathrm{AB} \\
\mathrm{BB}\end{array}$ & $\begin{array}{c}0 \\
27 \\
30\end{array}$ & $\begin{array}{r}0.00 \\
47.37 \\
52.63\end{array}$ & $\begin{array}{l}A= \\
B=\end{array}$ & $\begin{array}{l}0.237 \\
0.763\end{array}$ & $\begin{array}{l}0.0562 \\
0.3617 \\
0.5822\end{array}$ & $\begin{array}{c}3.20 \\
20.61 \\
33.18\end{array}$ & 5.485 \\
\hline \multirow{4}{*}{ 官 } & CSN1S1 & $\begin{array}{l}\mathrm{BB} \\
\mathrm{BC} \\
\mathrm{CC}\end{array}$ & $\begin{array}{c}101 \\
1 \\
0\end{array}$ & $\begin{array}{r}99.02 \\
0.98 \\
0.00 \\
\end{array}$ & $\begin{array}{l}B= \\
C=\end{array}$ & $\begin{array}{l}0.995 \\
0.005\end{array}$ & $\begin{array}{l}0.9900 \\
0.0100 \\
0.0000\end{array}$ & $\begin{array}{c}100.98 \\
1.01 \\
0.00\end{array}$ & 0.003 \\
\hline & CSN3 & $\begin{array}{l}\mathrm{AA} \\
\mathrm{AB} \\
\mathrm{BB}\end{array}$ & $\begin{array}{c}56 \\
39 \\
7\end{array}$ & $\begin{array}{r}54.90 \\
38.24 \\
6.86\end{array}$ & $\begin{array}{l}A= \\
B=\end{array}$ & $\begin{array}{c}0.74 \\
0.246\end{array}$ & $\begin{array}{l}0.5476 \\
0.3641 \\
0.0605\end{array}$ & $\begin{array}{c}55.86 \\
37.14 \\
6.17\end{array}$ & 0.205 \\
\hline & CSN2 & $\begin{array}{l}\text { A1 } \\
\text { A2 } \\
\text { A1A2 } \\
\text { A1B } \\
\text { A2B } \\
\text { A2A3 }\end{array}$ & $\begin{array}{c}21 \\
29 \\
37 \\
8 \\
6 \\
1\end{array}$ & $\begin{array}{r}20.59 \\
28.43 \\
36.27 \\
7.84 \\
5.88 \\
0.98\end{array}$ & $\begin{array}{l}\mathrm{A} 1= \\
\mathrm{A} 2= \\
\mathrm{A} 3= \\
\mathrm{B}=\end{array}$ & $\begin{array}{c}0.426 \\
0.5 \\
0.005 \\
0.069\end{array}$ & $\begin{array}{l}0.1815 \\
0.2500 \\
0.4260 \\
0.0588 \\
0.0690 \\
0.0050\end{array}$ & $\begin{array}{c}18.51 \\
22.25 \\
48.56 \\
6.88 \\
7.52 \\
0.52\end{array}$ & 5.627 \\
\hline & BLG & $\begin{array}{l}\text { AA } \\
\text { AB } \\
\text { BB }\end{array}$ & $\begin{array}{c}8 \\
54 \\
40\end{array}$ & $\begin{array}{r}7.84 \\
52.94 \\
39.22\end{array}$ & $\begin{array}{l}A= \\
B=\end{array}$ & $\begin{array}{l}0.343 \\
0.657\end{array}$ & $\begin{array}{l}0.1176 \\
0.4507 \\
0.4316\end{array}$ & $\begin{array}{l}12.00 \\
45.97 \\
44.03\end{array}$ & 3.104 \\
\hline
\end{tabular}

$* \mathrm{P} \leq 0,05$

For the cattle with 50-75\% HF, homozygous BB individuals clearly prevailed within 
the CSN1S1 polymorphism, reaching 94.74\%. Similarly, homozygous animals (AA) were prevalent in the polymorphism of CSN3, whereas heterozygotes prevailed in the polymorphisms of the milk proteins CSN2 and homozygotes prevailed for BLG.

Table 3

Frequencies of genes controlling milk protein polymorphism as well as observed and theoretical distribution of genotypes with different proportion of HF cattle genes in farm B (Genfrequenz des Milchproteinpolymorphismus sowie beobachtete und theoretische Genotypenverteilung in der untersuchten Kuhpopulation mit verschiedenem HF-Genanteil im Betrieb B)




In the group of cows with $75-100 \% \mathrm{HF}$, within the CSN1S1, 99.02\% of individuals were homozygotes $\mathrm{BB}$, which resulted from a high frequency of the allele CSN1S1B (0.995). Similarly, homozygotes prevailed in the polymorphism of CSN3. A higher frequency of heterozygous individuals was found within the milk proteins CSN2 and BLG, respectively CSN2 A1A2 (36.27\%) and BLG AB (52.94\%).

Table 3 presents the frequency of genotypes that control milk protein polymorphism, as well as the observed and theoretical distribution of genotypes in the studied population of cows with different share of HF breed in the genotype in farm $B$.

Three genotypes of CSN3 protein, $\mathrm{AA}, \mathrm{AB}$, and $\mathrm{BB}$, were found in the group of cows with $25-50 \%$ of HF. Homozygous CSN3 AA animals prevailed, representing $89.47 \%$. In the polymorphism of CSN2, heterozygotes prevailed. Within the BLG, three genotypes were found, i.e. $\mathrm{AA}, \mathrm{AB}$, and $\mathrm{BB}$. The highest frequency was represented by BLG BB individuals (52.63\%).

In the population of cows with 50-75\% HF, within the polymorphism of CSN1S1, homozygous BB individuals represented $95.12 \%$, which was a consequence of a high frequency of the allele CSN1S1 B (0.976). Within CSN3, also homozygous AA individuals represented a majority (63.41\%). In the BLG polymorphism, heterozygous $\mathrm{AB}$ individuals prevailed (56.10\%).

Within the genotypic group of $75-100 \%$ HF, the domination of homozygous individuals was recorded in the milk proteins CSN1S1 and CSN3, i.e. 0.977 and 0.842 for $\mathrm{BB}$ and $\mathrm{AA}$ respectively. Within the CSN2, heterozygotes dominated. Three genotypes were found for $\mathrm{BLG}(\mathrm{AA}, \mathrm{AB}$, and $\mathrm{BB})$. The percentages of genotypes $\mathrm{AB}$ and BB were equal, namely $41.44 \%$.

In all studied milk protein polymorphisms, the empirical distribution of genotypes corresponded to the theoretical distribution, so the entire population of cattle with different HF proportion remained in the genetic equilibrium.

\section{Discussion}

Casein, with its content in milk being about 2.5\%, is the most important milk protein for the cheese industry (PANICKE et al., 1998; FELEŃCZAK and SZAREK, 1987). Milk with higher content of casein is desired because of its better technological value, i.e. shorter time of flocculation (formation of casein clot in the process of cheese production), tougher clots, and an increased cheese production yield (GRAML and PIRCHNER, 2003; HARTUNG and GERNAND, 1997; KRZYŻEWSKI et al., 1997). The performance of technological processes of cheese production depends on the structure of the kappa-casein gene (ZATOŃ, 1999; GERNAND and HARTUNG 1997). In the studied herd, a decreasing frequency of the phenotype CSN3B was observed to accompany an increase in the proportion of HF genes (Table 1). According to KAMIŃSKI (1994), reduced frequency of the CSN3B allele results from a negative effect of still progressive expansion of Holstein-Friesian cattle, for which a low frequency of the desired CSN3B allele is a characteristic trait.

Concentration of individual milk protein fractions and their interrelations depend on the polymorphic form of the given protein determined by a mutation that is expressed through a substitution of one ore more amino acids with others at the given site. These relatevily small changes in the polypetide chain have a significant influence on chemical composition and physicochemical properties of total milk protein (GRUPE and SCHWERIN, 1998; KRZYŻEWSKI et al., 1998). 
Comparing our studies with those by LITWIŃCZUK et al. (1998b), who studied 351 crossbreds with the Holstein-Friesian breed of cattle, similar phenotypes of milk proteins were found. The frequency of milk protein polymorphism phenotypes in a majority of cases corresponded to the expected frequency. Only in the CSN3 polymorphism in the group of crossbreds with less than $50 \%$ of HF genes, significant differences were found between the observed and expected genotype frequencies. Significant differences were also found in the group of 25.1-50.0\% HF in the polymorphism of CSN2, which was confirmed with own studies (Table 2).

Investigating into the frequency of CSN3 of milk revealed prevalence of the gene A over B within all the genotypic groups in both farms (Tables 2 and 3). MICHALAK (1997), who studied cattle with a high proportion of the Holstein-Friesian cattle genes, found the frequencies of kappa-casein alleles A and B respectively 0.8092 and 0.1908. LITWIŃCZUK and BARŁOWSKA (1998), who studied crossbreds with the HF breed in private farms, found that heterozygotes CSN3 AB prevailed (55.7\%). JUSZCZAK et al. (2001) found homozygotes CSN3 AA to be prevalent. PANICKE et al. (1998), who studied Black-and-White cattle, found kappa-casein genotypes AE and BE. STRZAŁKOWSKA et al. (1998) stated that about 3\% of currently managed Blackand-White (BW) cattle were kappa-casein homozygotes BB.

LITWIŃCZUK et al. (1998a), who studied populations of BW cows, Jersey cows, and their crossbreds with various addition of HF, found that the lowest frequency of BLG AA homozygotes was among the cows with $0.1-25 \%$ of $\mathrm{HF}$ and $\mathrm{BW}$; these were at the same time the groups where the proportion of BLG AB heterozygotes was highest. STRZAŁKOWSKA et al. (1998) reported the frequencies of BLG alleles A and B in populations of BW cattle with a high proportion of HF genes, respectively 0.41 and 0.59. PANICKE et al. (1998), who studied Black-and-White cattle, recorded frequencies betalactoglobulin genotypes $\mathrm{AA}, \mathrm{AB}$, and $\mathrm{BB}$ at the level of, respectively, 0.11, 0.51, and 0.38. According to KAMIŃSKI et al. (1996), the frequencies of BLG alleles A and B in Holstein-Friesian cattle ranges between 35.1-41\% and 59-65\%, respectively.

Results of studies on milk protein polymorphism can be used as an additional criterion for selecting sires in the dairy cattle herds. Selection for respective BLG and CSN3 genotypes would contribute to an increased casein content in milk, improved technological quality of milk, and increased cheese production yield. Selection for the mentioned alleles represents a relatively easy task, as they are located on different chromosomes, so no couplings between them occur. Such a direction of selection would not reduce milk yield, but it would significantly contribute to an improvement of milk processing parameters (FREYER et al. 1998; STRZALKOWSKA et al. 1998). This procedure will enable collection of cow herds that produce milk of improved processing quality for the needs of the cheese industry.

\section{Conclusions}

A genetic variability of milk protein polymorphisms was found in the studied farms. The highest milk content of casein was found in farm B in all genotypic groups of cows, while the highest percentage milk content of whey proteins was found in farm A in cows with $25-50 \%$ HF; in the remaining groups the level was similar in both farms. The frequency of the allele BLG B, which is desired in cheese production, was highest in the group of cows with $50-75 \% \mathrm{HF}$ in farm A. 
The frequency of desired genetic variants of CSN3B, in relation to the technological value of milk for cheese production, was higher in farm $\mathrm{A}$ in all genotypic groups of cows.

Identification of desired genes encoding milk proteins is of high importance in the countries and regions where cheese industry represents an important branch of economy and the quality of raw material and its technological properties considerably influence the value of the end product as well as output capacity and economical results.

\section{References}

ASCHAFFENBURG, R.; DREWRY, J.;

New procedure for the routine determination of the various non-casein proteins in milk. Proc. of XV Int. Dairy Congress, 3 (1959)

FELEŃCZAK, A.; SZAREK, J.;

Milk composition and protein polymorphism in milk of BWL and BRL cows and crossbreds BWL x HF and BRL x HF. Zesz. Probl. Postęp. Nauk Rolniczych, z. 332 (1987), 81-84 [In Polish]

FREYER, G.; PANICKE, L.; LIU, Z.; ERHARDT, G.:

Examination of genetic linkage of QTL for milk production traits to milk protein loci in a family analysis compared with results of a population analysis. Arch. Tierz., Dummerstorf 41 (1998) 6, 545552

GERNAND, E.; HARTUNG, H.:

Untersuchungen zu Einflußgrößen auf Zusammensetzung und Käsereitauglichkeit von Rohmilch einzelner Kühe. 2. Mitt.: Untersuchung zur Variation der Milchgerinnung und deren Ursachen an Einzelmilchproben. Arch. Tierz., Dummerstorf 40 (1997) 3, 225-238

GRAML, R.; PIRCHNER, F.:

Effects of milk protein loci on content of their proteins. Arch. Tierz., Dummerstorf 46 (2003) 4, 331340

GRUPE, S.; SCHWERIN, M.:

Mapping of Quantitative Trait Loci on Chromosome 23 in German Holstein Cattle Families. Arch. Tierz. Dummerstorf 41 (1998) 3, 225-235

HARTUNG, H.; GERNAND, E.:

Untersuchungen zu Einflußgrößen auf Zusammensetzung und Käsereitauglichkeit von Rohmilch einzelner Kühe. 1 Mitt.: Voruntersuchungen zur Sicherung konstanter Meßbedingungen und zur Bedeutung fixer Einflußfaktoren auf die Milchgerinnung. Arch. Tierz., Dummerstorf 40 (1997) 3, 215223

JANN, O.; O; PRINZENBERG, E. M.; BRANDT, H.; WILLIAMS, J. L.; AJMONE-MARSAN, P.;

ZARAGOZA, P.; ÖZBEYAZ, C.; ERHARDT, G.: Intragenic haplotypes at the bovine CSN1S1 locus. Arch. Tierz., Dummerstorf 45 (2002) 1, 13-22

JUSZCZAK, J.; ERHARDT, G.; KUCZAJ, M.; ZIEMIŃSKI, R.; PANICKE, I.:

Relations between genetic variance of k-casein and b-lactoglobulin and performance of Black-andWhite and Polish Red cattle. Arch. Tierz., Dummerstorf 44 (2001) 3, 239-249

KAMIŃSKI, S.;

Kappa-casein gene and possibilities of its application in cattle selection. Prz., Hod., 3 (1994), 8-10 [In Polish]

KAMIŃSKI, S.; CZARNIK, U.; ZABOLEWICZ, T.:

Programme of practical application of identification of kappa-casein gene and beta-lactoglobulin gene. Prz. Hod. 1 (1996), 4-5 [In Polish]

KRZYŻEWSKI, J.; STRZAŁKOWSKA, N.; RYNIEWICZ, Z.;

Genetic and environmental factors influencing protein content in milk of cows. Prz., Hod., 8 (1997), 8-11 [In Polish]

KRZYŻEWSKI, J.; STRZAŁKOWSKA, N.; RYNIEWICZ, Z.;

Relationship between genetic polymorphism of proteins and yield, chemical composition and technological parameters of cow milk. Prace i Materiały Zootechniczne, 52 (1998), 7-35 [In Polish]

LITWIŃCZUK, A.; BARŁOWSKA, J.; FLOREK, M.; KĘDZIERSKA, M.;

A comparison of milk protein polymorphisms between private farms and experimental stations of the Agricultural University. Ann. Univ. Mariae Curie- Skłodowska, Lublin- Polonia, SECTIO EE, Vol. XIV, 10 (1996), 55-57 [In Polish] 


\section{LITWIŃCZUK, A.; BARŁOWSKA, J.;}

Milk proteins and their polymorphism in milk of cows in the middle-eastern regions of Poland. Mat. of Sci. Conf. "Application of current basic science achievements”, VIth Winter School, Kamianna 15-22 March. Fundacja Ratowania Fauny i Flory Karpat i Podkarpacia, Kraków, (1998), 290-300 [In Polish]

LITWIŃCZUK, A.; LITWIŃCZUK, Z.; BARŁOWSKA, J.; FLOREK, M.;

Productivity and chemical composition of milk with particular reference to protein and its fractions in Black-and-White cows, Jersey cows, and cows with various proportion of HF genes. Mater. Konf. Nauk. Wrocław 25-26.06.1998, Zesz. 331 (1998a), 149-155 [In Polish]

LITWIŃCZUK, A.; BARŁOWSKA, J.; DROZD, A.; POKORA, B.;

Milk yield and protein content and its polymorphism in Black-and-White cows and crossbreds with various proportion of HF genes managed in private farms. Ann. Univ. Mariae Curie- Skłodowska Lublin-Polonia, SECTIO EE, Vol. XVI.1 (1998b), 1-6 [In Polish]

MICHALAK, W. B.:

Application of starch gel electrophoresis for simultaneous determination of phenotypes of four main milk proteins. Part I. Biul. Z.H.D.Z. PAN 15 (1969), 75-88 [In Polish]

MICHALAK, W. B.:

Milk protein polymorphism in dairy cattle herd of high proportion of Holstein-Friesian genes and its relation with some performance traits. Rocz. Nauk. Zoot. t. 24. z. 2 (1997), 7-21 [In Polish]

PANICKE, L.; FREYER, G.; ERHARDT, G.:

Effekte von Milchproteingenvarianten auf Fruchtbarkeitseigenschaften beim Schwarzbunten Rind. Arch. Tierz., Dummerstorf 41 (1998) 5, 447-454

PETERSON, R. F.; KOPFLER, F. C.:

Detection of new types of caseins by polyacrylamide gel electrophoresis at acid $\mathrm{pH}$ : a proposed

RUSZCZYC, Z: nomenclature., Bioch. And Biophys. Research Communications, t. 22 (1966), 368

SCHMIDT, D.C;

Experimental Methods in Animal Science. PWRiL (1978). [In Polish]

Starch gel electrophoresis of kappa-casein. Biochim. Biophys. Acta , 90 (1964), 411

STRZAŁKOWSKA, N.; KRZYŻEWSKI, J.; RYNIEWICZ, Z.;

Purposefulness of introduction of milk proteins polymorphism criterion to breeding practice. Prz.,

ZATOŃ, M.; Hod., 10 (1998), 23-14 [In Polish]

Importance of kappa-casein polymorphism for cattle breeding. Pr. i Mater. Zootech. 54 (1999), 7-19 [In Polish]

Received: 2003-09-05

Accepted: 2004-02-27

Author's address

EWA CZERNIAWSKA-PIĄTKOWSKA, PhD; HENRYK KAMIENIECKI, Prof.;

RENATA PILARCZYK, pPhD; EDYTA RZEWUCKA, Msc

Department of Ruminant Animal Science; Agricultural University of Szczecin

Akademia Rolnicza w Szczecinie

Katedra Nauk o Zwierzętach Przeżuwających

ul. Doktora Judyma 10

71-460 Szczecin

Poland

E-Mail: E.Czerniawska-Piatkowska@biot.ar.szczecin.pl ewaczp@wp.pl 